\title{
Post-Circumcision Complications in a Tertiary Institution in Nigeria: A Three-Year Study
}

\author{
Nwokoro Cc ${ }^{1}$, Fatungase O.M ${ }^{2}$, Salami B.A ${ }^{1}$, Shonubi A M O ${ }^{1}$, Tade O.A ${ }^{1}$ \\ Ayoade B A ${ }^{1}$
}

1. Department Of Surgery

2. Department Of Anaesthesia \& Intensive Care,

Olabisi Onabanjo University Teaching Hospital, Sagamu

\begin{abstract}
Background: Circumcision is an operation practiced in various parts of the world for different reasons. In Nigeria today, circumcision is a customary rite for males and occasionally done in females in some parts of the country.

The process of circumcision which appear simple to the untrained hands could be associated with severe complications and may even result in mortality.

AIM: To determine the spectrum of post-circumcision complications seen at Olabisi Onabanjo University Teaching Hospital (OOUTH), Sagamu between July 2005 - June 2008 (36 months).

DESIGN: A three-year retrospective study of post-circumcision complications seen during the study period.

SETTING: Paediatric Surgery Division, Department of Surgery, OOUTH, Sagamu.

METHODOLOGY: Case-notes of all children with post-circumcision complications were retrieved from the medical record department and analysed using SPSS version 10.

RESULT: Twenty-two cases were studied. 21 (95.5\%) were males while 1 (4.5\%) was a female. All the cases studied were operated outside the hospital and referred to the study centre for further management of their complications. The age range was 12 days to 3 years. Circumcision was done during the neonatal period in 16 (72.7\%) and outside the neonatal period in $6(27.3 \%)$. The indications for circumcision in all the cases were non-medical and included religious, cultural and social reasons.

The post-circumcision complications managed during the study period were the following: buried penis 7 $(31.8 \%)$, incomplete removal of prepuce $6(27.2 \%)$, urethro-cutaneous fistula $4(18.2 \%)$, severe anemia from haemorrhage 2 (9.0\%), dermoid cyst of the clitoris 1 (4.5\%) retained plastibell ring 1 (4.5\%), meatal stenosis 1 (4.5\%). Two of the patients with urethro-cutaneous fistula had recurrence after repair.

CONCLUSION: Circumcision is a surgical procedure commonly done during the neonatal period in our environment for males mostly and rarely females. It is sometimes followed by severe complications.
\end{abstract}

\section{Introduction}

Circumcision is an operation practiced in various parts of the world for different reasons. In Nigeria today, circumcision is a must for males.

In some parts of the country, uncircumcised children are seen as abnormal and considered to be socially inferior. Hence, children are mostly circumcised for non-medical reasons in this part of the world. ${ }^{1}$

However, the practice of circumcision in adult and both sexes have been reported by some authors. ${ }^{2,3,4,5}$ The common medical indications for circumcision include phimosis and recurrent urinary tract infection. ${ }^{6,7}$

Recently, some authors have reported the role of circumcision in preventing Human Immunodeficiency Virus infection in males. ${ }^{8,9}$

Complications of circumcision reported by several authors include bleeding, excessive redundant foreskin, granuloma formation, secondary chordee, dermoid cyst, partial and complete amputation of the glands penis, preputio-glandular fusion, meatal stenosis and urethro-cutaneous fistula. ${ }^{1,2,6,10,11,12}$

The complications referred to our centre for further management during the study period (July 2005 June 2008) formed the basis of this 3-year review.

\section{Patients And Methods}

Case-notes of all children with post-circumcision complications were retrieved from the medical record department and the observations presented in figures and tables. 


\section{Results}

Twenty-two cases were studied. 21 (95.5\%) were males while 1 (4.5\%) was a female (Table 1). All the cases studied were operated outside the hospital and referred to the study centre for further management of their complications.

The age range was 12 days to 3 years. Circumcision was done during the neonatal period in $16(72.7 \%)$ and outside the neonatal period in $6(27.3 \%)$. The indications for circumcision in all the cases were non-medical and included religious, cultural and social reasons.

The post-circumcision complications managed during the study period were the following: buried penis 7 (31.8\%), incomplete removal of prepuce $6(27.2 \%)$, urethro-cutaneous fistula $4(18.2 \%)$, severe anemia from haemorrhage $2(9.0 \%)$, dermoid cyst of the clitoris $1(4.5 \%)$ retained plastibell ring $1(4.5 \%)$, meatal stenosis 1 (4.5\%) (Table 2). The 8 patients with buried penis had refashioning done while those with incomplete removal of prepuce had the redundant prepuce excised. Urethro-cutaneous fistula was closed through urethroplasty, severe anemia was corrected by blood transfusion, retained pastibell ring was cut and removed, meatal stenosis had meatoplasty.

Two of the patients with urethro-cutaneous fistula had recurrence after repair.

TABLE 1: SEX DISTRIBUTION OF PATIENTS

WITH POST-CIRCUMCISION COMPLICATIONS

\begin{tabular}{|l|l|l|}
\hline SEX & NUMBER & PERCENTAGE (\%) \\
\hline MALE & 21 & 95.5 \\
\hline FEMALE & 1 & 4.5 \\
\hline TOTAL & $\mathbf{2 2}$ & $\mathbf{1 0 0}$ \\
\hline
\end{tabular}

TABLE 2: DISTRIBUTION OF POST-CIRCUMCISION COMPLICATIONS

\begin{tabular}{|l|l|l|}
\hline $\begin{array}{l}\text { POST-CIRCUMCISON } \\
\text { COMPLICATION }\end{array}$ & NUMBER & PERCENTAGE (\%) \\
\hline BURIED PENIS OF & 7 & 31.8 \\
\hline $\begin{array}{l}\text { INCOMPLETE REMOVAL } \\
\text { PREPUCE }\end{array}$ & 27.2 \\
\hline URETHRO-CUTANEOUS FISTULA & 4 & 18.2 \\
\hline SEVERE ANEMIA & 2 & 9.0 \\
\hline DERMOID CYST OF THE CLITORIS & 1 & 4.5 \\
\hline RETAINED PLASTIBELL RING & 1 & 4.5 \\
\hline MEATAL STENOSIS & 1 & 4.5 \\
\hline TOTAL & $\mathbf{2 2}$ & $\mathbf{1 0 0}$ \\
\hline
\end{tabular}

\section{Discussion}

In this review, it was observed that circumcision was mostly carried out in the neonatal period and this finding is similar to the report of other authors. ${ }^{1,6,13}$

However, some writers have advised against routine neonatal circumcision because of the associated complications. $^{14,15}$

Furthermore, in some tribes in Nigeria and Southern Africa, circumcision is done in adult males and females as part of initiation into adulthood. ${ }^{2,3,5,16}$

The indications for circumcision were for non-medical reasons and these included religious, social and cultural. This is similar to indications documented in other centres ${ }^{1,3,4,14,17}$.

The complication rate of circumcision vary from region to region depending on who performs the procedure, and the patients involved. However, complication rate of $20.2 \%$ was observed by Okeke et al in Ibadan1, while Shittu and Shokunbi in a similar study on haemophiliacs in Ibadan reported a complication rate of $50 \%$.

The complications we managed resulted from circumcision done outside the study centre.

Buried penis was the most common complication in this review followed by incomplete removal of the prepuce and urethro-cutaneous fistula; other complications reported from different centres include hemorrhage, excessive foreskin, partial amputation of the glans penis, labial occlusion, implantation dermoid cyst, urethrocutaneous fistula, meatal stenosis and preputio-glandular fusion. ${ }^{1,2,10,11,12,18}$

The cases of post-circumcision complications seen in this review were managed as indicated and no death was recorded. 


\section{Conclusion}

The study shows that circumcision is a commonly performed operation which is prone to grave complications especially when carried out by non-trained personnel. Buried penis was the commonest postcircumcision complication observed in this study.

\section{References}

[1]. Okeke LI, Asinobi AA, Ikuerowo OS, Epidemiology of complication of male circumcision in Ibadan, Nigeria. BMC urol. 2006;6:21. PubMed

[2]. Agugua N.E.N, Egwuatu V.E. Female Circumcision: Management of Urinary Complications.

[3]. J Trop Pediatr 1982;28:248-252. PubMed

[4]. Myers RA, Omorodion FI, Isenalumhe AE, Akenzua GI.

[5]. Circumcision: its nature and practice among some ethnic groups in southern Nigeria.

[6]. Soc Sci Med. 1985;21:581-8. PubMed

[7]. ORTUN M, David LB. Traditional male circumcision in the Eastern cape-scourge or blessing? SAMJ 2007;97:371-373. PubMed

[8]. Magoha GA. Circumcision in various Nigeria and Kenya hospitals.

[9]. East Afr med J. 1999, 76:583-586. PubMed

[10]. Ben Chaim J, Levin PM, Binyamin J, Hardak B, Ben-Meir D, Mor Y: Complications of circumcision in Israel: a one year multicenter survey. Isr Med Assoc J 2005, 7:368-70. PubMed

[11]. Cathcart P, Nuttall M, van der Meulen J, Emberton M, Kenny S.E. Trends in paediatric circumcision and its complications in England between 1997 and 2003. British Journal of Surgery 2006,93:885-890. PubMed

[12]. Adamson S.M, Hans W.P, Ronald H.M, Joseph I.I. Prevalence of complications of male circumcision in Anglophone Africa: a systematic review. BMC Urol. 2007; 7: 4. PubMed

[13]. Bailey RC, Muga R, Poulussen R, Abicht H: The acceptability of male circumcision to reduce HIV infections in Nyanza province, Kenya. AIDS Care 2002, 14:27-40. PubMed

[14]. Shittu OB, Shokunbi WA. Circumcision in hemophiliacs: the Nigerian experience.

[15]. Hemophilia. 2001;7:534-6. PubMed

[16]. Yegane RA, Kheirollahi AR, Salehi NA, Bashashati M, Khoshdel JA, Ahmadi M. Late complications of circumcision in Iran. 1: Pediatr Surg Int. 2006;22(5):442-5. PubMed

[17]. Ahmed A.; Mbibi N.H.; Dawam D.; Kalayi G.D. Annals of Tropical Paediatrics:

[18]. International Child Health, 1999;19:113-117. PubMed

[19]. WILLIAMS N, KAPILA L. Complications of circumcision. 1993;80:231-1236. PubMed

[20]. Machmouchi M, Alkhotani A. Is neonatal circumcision judicious.

[21]. Eur J pediatr sur. 2007;17:266-269. PubMed

[22]. Neonatal circumcision revisited. Fetus and Newborn Committee, Canadian Paediatric Society. Cmaj. 1996;154:769-80. PubMed.

[23]. Egwuatu V.E, Agugua N.E.N. Complications of Female Circumcision in Nigerian Igbos. BJOG: An International Journal of Obstetrics \& Gynaecology, 2005;88:1090 - 1093. PubMed

[24]. Badejo OA. Complications of Circumcision: The Ife Experience.

[25]. Nigerian Medical Practitioner 1983;5:103-109. PubMed

[26]. Ceylan K, Burhan K, Yılmaz Y, Can S, Kuş A, Mustafa G. Severe complications of circumcision: An analysis of 48 cases . Journal of Pediatric Urology, 2003; 3:32 - 35. PubMed 